\title{
Comments on "Plasma Phasography"
}

\section{Korsbech, Uffe C C}

\section{Published in:}

Review of Scientific Instruments

Link to article, DOI:

$10.1063 / 1.1684134$

Publication date:

1969

\section{Document Version}

Publisher's PDF, also known as Version of record

Link back to DTU Orbit

Citation (APA):

Korsbech, U. C. C. (1969). Comments on “Plasma Phasography". Review of Scientific Instruments, 40(7), 969969. https://doi.org/10.1063/1.1684134

\section{General rights}

Copyright and moral rights for the publications made accessible in the public portal are retained by the authors and/or other copyright owners and it is a condition of accessing publications that users recognise and abide by the legal requirements associated with these rights.

- Users may download and print one copy of any publication from the public portal for the purpose of private study or research.

- You may not further distribute the material or use it for any profit-making activity or commercial gain

- You may freely distribute the URL identifying the publication in the public portal

If you believe that this document breaches copyright please contact us providing details, and we will remove access to the work immediately and investigate your claim 


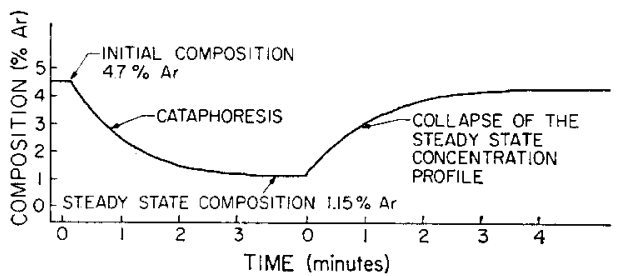

Frg. 1. Argon composition at the anode in a $\mathrm{He}+\mathrm{Ar}$ mixture vs time for cataphoresis and for back diffusion after the discharge is turned off. Current- $100 \mathrm{~mA}$; pressure $-3.2 \mathrm{~mm}$.

The disturbance, associated with sample withdrawal in the above technique, may be eliminated by having each gas stream flow through a $60 \mathrm{~W}$ lamp. In the flow system the lamp filaments must be calibrated for both composition and flow rate. In the nonflow system involving endbulbs the $60 \mathrm{~W}$ lamp is connected directly behind a porous molybdenum screen serving as the anode. The molybdenum screen is rolled tightly inside a $9.5 \mathrm{~mm}$ Kovar glass-to-metal seal which is grounded. The gas discharge system is cooled by a constant temperature water bath. For typical operating conditions in nonflow cataphoretic systems, the product of the Grashof and Prandtl numbers is $\sim 10^{-8}$, thereby indicating that heat transfer from the filament by free convection is negligible. ${ }^{12,13}$ Although the $60 \mathrm{~W}$ lamp filament is in a close helix-in-helix winding, a simple conduction analysis of a straight thin wire predicts the calibration curves quite accurately. Binary mixtures with helium or hydrogen are ideally suited to this technique because of their relatively high thermal conductivities. The lamp filament provides one leg in a Wheatstone bridge. The imbalance of the bridge circuit is amplified and recorded on a strip chart. Typical results, shown in Fig. 1, are in agreement with theory. ${ }^{14}$

* This work was supported ${ }^{\top}$ in part with funds provided by the United States Atomic Energy Commission.

1 E. C. C. Baly, Phil. Mag. 35, 200 (1893).

2 F. M. Penning, Physica 1, 763 (1933).

${ }^{3}$ M. J. Druyvesteyn and N. Warmoltz, Phil. Mag. 17, 1 (1934).

${ }^{4}$ R. Riesz and G. H. Dieke, J. Appl. Phys. 25, 196 (1954).

${ }^{5}$ A. L. Schmeltekopf, Jr., J. Appl. Phys. 35, 1712 (1964).

${ }^{6}$ V. R. Mittelstadt and H. J. Oskam, Rev. Sci. Instrum. 32, 1408 (1961).

${ }^{7}$ N. A. Matveeva, Bull. Acad. Sci. USSR, Phys. Ser. 23, 1009 (1959).

${ }^{8} \mathrm{~J}$. Freudenthal, Physica 36, 365 (1967).

${ }^{9}$ H. D. Beckey, W. E. Groth, and K. H. Welge, Z. Naturforsch. $8 a, 556$ (1953).

${ }^{10}$ James E. Flinn, Doctoral dissertation, University of Cincinnati (University Microfilms, Inc., Ann Arbor, Michigan, 1965), p. 130.

${ }^{11} \mathrm{~J}$. E. Flinn and R. H. Price, Ind. Eng. Chem. Process Design Develop. 5, 75 (1966).

${ }^{12}$ N. V. Tsederberg, Thermal Conductivity of Gases and Liquids (The MIT Press, Cambridge, Massachusetts, 1965), Chap. 1, p.22.

${ }^{13}$ William H. McAdams, Heat Transmission (McGraw-Hill Book Co., New York, 1954), 3rd ed., Chap. 7, p. 176.

${ }^{14}$ F. H. Shair and D. S. Remer, J. Appl. Phys. 39, 5762 (1968).

\section{Letter to the Editor}

THE REVIEW OF SCIENTIFIC INSTRUMENTS

\section{Comments on "Plasma Phasography"}

\author{
[Herman M. Presby and David Finkelstein, \\ Rev. Sci. Instrum. 38, 1563 (1967)] \\ U. KORSBECH \\ Laboratory for Flectrophysics, The Technical University, \\ Lyngby, Denmark
}

(Received 17 February 1969)

$T$ HE phase contrast microscope and the theory developed for the plasma phasography ${ }^{1}$ are based mainly on the assumptions that one is dealing with microscopic inhomogeneities with characteristic dimensions comparable to the wavelength of the light. However, this is not the case in the experiments performed by the authors. They actually dealt with inhomogeneities, whose typical dimensions normal to the direction of propagation of the light are several orders of magnitude larger than the wavelength of the light. This should mean that the theory developed in the article is not applicable to the experiments.
VOLUME 40, NUMBER 7

JULY 1969

The "phasograms" shown in the article can be explained as follows: The light beam used is diffracted just as in the usual schlieren technique and no part of it passes through the inhomogeneity as an undeviated wave. The diffraction will take place in every region where there is a gradient of the integrated electron density across the depth of the field (which must be larger than the plasma dimensions in that direction). When the deviation at the mirror is larger than the radius of the conjugate area, the beam is reflected from the mirror and reaches the image plane. When the deviation is smaller, the beam hits the conjugate area, from where only a small fraction is reflected to the image plane. According to this explanation one should expect an even better contrast at the image plane by using a mirror with a hole at the position of the conjugate area. A name such as "mirror schlieren" would perhaps cover the technique better than the name "phasograph."

Herman M. Presby and David Finkelstein, Rev. Sci. Instrum.'38' 1563 (1967). 